Research Journal of Dairy Sciences 4 (2): 12-17, 2010

ISSN: 1993-5277

(C) Medwell Journals, 2010

\title{
Effect of Different Varieties of Date Palm Paste Incorporation on Quality Characteristics of Yoghurt
}

\author{
${ }^{1}$ P.S. Kadam, ${ }^{1}$ R. V. Kale and ${ }^{2}$ Syed Imran Hashmi \\ ${ }^{1}$ Department of Food Microbiology, \\ ${ }^{2}$ Department of Food Trade and Business Management, College of Food Technology, \\ Marathwada Agricultural University, Parbhani (MS), India
}

\begin{abstract}
Yoghurt was prepared by using two different varieties of date palm paste cultivars viz. Behri and Safri at varying levels of concentration. The efforts were made to investigate the influence of different varieties of date paste on physical properties (settling time and synersis), chemical characteristics ( $\mathrm{pH}$, acidity, moisture, fat, protein and total soluble solids), sensory quality (appearance, colour, flavour, taste, texture and overall acceptability). The data generated during present investigation revealed that date palm pastes from both varieties could be use as a novel ingredient in enhancing the quality characteristics of yoghurt. Yoghurt sample prepared with incorporation of $10 \%$ date palm paste of Safri variety resulted in superior organoleptic as well as chemical characteristics compared to other treated samples, justifying its suitability in date palm paste yoghurt preparation.
\end{abstract}

Key words: Phoenix dactylifera, date palm paste, yoghurt, Behri, Safri, quality

\section{INTRODUCTION}

Yoghurt is a cultured milk product and generally fermented with mixture of two species i.e., Lactobacillus bugaricus and Streptococcus thermophilus. Usually, it contains $12-14 \%$ total milk solids and has a soft, friable custard like consistency and a clean distinct acid flavour. Yoghurt supplies high quality of protein and is excellent source of calcium, phosphorus and potassium and contains significant quantities of general vitamins (Meydani, 2006). In recent years, yoghurt has become a popular vehicle of incorporating the probiotic species viz. L. acidophilus and B. bifidium (Vinderola et al., 2000). Yoghurt is valuable adjunct to any healthy diet and the presence of $\alpha$-D-galactosidase activity in probiotic yoghurt indicates its suitability for lactose-intolerant infants (Sarkar and Mishra, 1998). Yoghurt is valued for controlling the growth of bacteria and incurring intestinal diseases like constipation, diarrhea and dysentery. Yoghurt is also effective in curing the blood cholesterol (Miller et al., 2000).

As milk protein, fat and lactose components undergo partial hydrolysis during fermentation, yoghurt is an easily digested product of milk (Rasic and Kurmann, 1978; Robinson and Tamime, 1975). Date palm (Phoenix dactylifera L.) is one of the oldest fruit trees in the world (Yousif et al., 1987). Different date palm varieties have been developed by thousands of years of selection of seedlings and only those possessing desirable characteristics have been propagated. Most commonly grown date varieties are Berhi, Dayri, Deglet, Noor, Halawy ('Halawi'e), Khadrawy ('Khadrawi'), Safri, Sayer.

Date paste used in variety of food preparation by chefs all around worlds has a rich content of minerals like potassium that are vital for human development while it is free in unnecessary components like sodium and cholesterol.

Date paste is largely used as a thickening and gelling agent in different types of processed food products like jams, jellies, soft cheeses, yoghurts and various confectionaries like cookies, cakes, breads and muffins. It is rich in various nutrients, from appetizers and main dishes to desserts and beverages. Date paste is today added to a large variety of food preparations (Ahmed and Ramaswamy, 2006).

The date fruit because of its tannin content is used medicinally as a detersive and astringent in intestinal troubles. It is taken to relieve fever, cystitis, gonorrhea, edema, liver and abdominal troubles and it is also said to counter-react alcohol intoxication (Al-Shahib and Marshall, 2003).

Recently there has been increasing trends to fortify the product with fruits. Generally, plain yoghurt is fortified with fruit to get the fruit yoghurt. Fruits may be used in

Corresponding Author: P.S. Kadam, Department of Food Microbiology, College of Food Technology, Marathwada Agricultural University, Parbhani (MS), India 
fresh, freeze, dried or canned state. The amount of fruit added may range from 10-30\% (Helferich and Westhoff, 1980 ). Date paste recognized its utility in various value added food products like jam, jelly, beverages and confectioneries. It was hypothesized that date paste could also be utilized as a value enhancer in case of milk based fermented product like yoghurt. Hence in present investigation, efforts were made to design a research project for preparation of date paste from two different varieties viz. Behri and Safri and its utilization in yoghurt with varying levels of concentration. Further, prepared yoghurt was analyzed for chemical, sensorial and nutritional values.

\section{MATERIALS AND METHODS}

The present investigation was conducted at the Department of Food and Industrial Microbiology, College of Food Technology, Marathwada Agricultural University, Parbhani (MS), India. The date palm fruit of two varieties viz. Berhi and Safri were obtained from local market of Parbhani and Mumbai. Cow milk of red sindhi breed was obtained from Department of Animal Husbandry and Dairy Science, MAU, Parbhani. Pure culture of Streptococcus thermophillus and Lactobacillus delbrueckii ssp. Bulgaricus were obtained from National Chemical Laboratory, NCIM, Pune.

Composition MRS Media: Suspend all ingredients in $920 \mathrm{~mL}$ distilled water and heat to boiling to dissolve the medium completely. Sterilize the media in autoclave at $15 \mathrm{lbs}$ pressure for $15 \mathrm{~min}$. Proteose peptone $\left(10 \mathrm{~g} \mathrm{~L}^{-1}\right)$, yeast extract $\left(5.0 \mathrm{~g} \mathrm{~L}^{-1}\right)$, beef extract $\left(10 \mathrm{~g} \mathrm{~L}^{-1}\right)$, dextrose $\left(20 \mathrm{~g} \mathrm{~L}^{-1}\right)$, Tween $-80\left(1.0 \mathrm{~g} \mathrm{~L}^{-1}\right)$, a mmonium citrate $\left(2.0 \mathrm{~g} \mathrm{~L}^{-1}\right)$, sodium acetate $\left(5.0 \mathrm{~g} \mathrm{~L}^{-1}\right)$, magnesium sulphate $\left(0.1 \mathrm{~g} \mathrm{~L}^{-1}\right)$, manganese sulphate $\left(0.05 \mathrm{~g} \mathrm{~L}^{-1}\right)$, dipotassium phosphate $\left(2.0 \mathrm{~g} \mathrm{~L}^{-1}\right)$.

Chemicals: Chemicals used in this investigation were of analytical grade. They were obtained from Department of Food and Industrial Microbiology, College of Agricultural Technology, MAU, Parbhani.

Physico-chemical analysis of date palm fruit: Date palm paste processed by different methods were analyzed for moisture content, protein, fat, reducing sugars, total soluble solids, mineral content, using standard chemicals and/or physical procedure (AOAC, 1990). Titratable acidity of the pulp was determined by titration against 0.1 $\mathrm{N}$ sodium hydroxide. The $\mathrm{pH}$ of date palm paste was determined by using Perkin Elmer $\mathrm{pH}$ meter.

Preparation of date paste: Ripe fruit with firm texture, uniform in size and maturity were used for the experiment.
After cleaning the fruits, preliminary trials were conducted to standardize the methods of preparation of paste for this purpose. The optimum quality fruits of two different varieties were selected and manual separation of seed was carried out. Further, the fruit was cut into small pieces and grinder to obtained paste.

\section{Preparation of yoghurt \\ Preparation of starter culture (mother culture): The} culture which was obtained from Subculturing i.e., Streptococcus thermophillus and Lactobacillus delbrueckii sp. Bulgaricus was inoculated in conical flask containing sterilized $50 \mathrm{~mL}$ cow milk in laminar flow. Then, the milk was incubated at $42-45^{\circ} \mathrm{C}$ till the firm coagulum was formed.

Preparation of batch culture: Batch culture was prepared by inoculating $3 \%$ of mother culture into $200 \mathrm{~mL}$ of sterilized cow milk and incubated at $42-45^{\circ} \mathrm{C}$ till firm coagulum was formed. The bulk culture was stored in refrigeration.

Raw materials: The main raw material of yoghurt is fresh cow's milk. The milk contains about $13 \%$ TSS including $3.5 \%$ fat. Skim Milk Powder (SMP) was used for fortification of the liquid milk.

Standardization/mixing: Medium-fat yoghurt was produced, containing $1.5 \%$ milk fat. Centrifugal separation is used to remove about $2 \%$ of fat from the initial liquid milk and clarify the raw milk. The milk was fortified with milk proteins to produce a thick-body yoghurt product. Nonfat Dry Milk (NFDM) at the rate of $4 \%$ is usually added. Milk protein stabilizers used to prevent whey separation (syneresis) of yoghurt are added at the rate of about $0.3 \%$.

Homogenization: The mixture of milk ingredients was homogenized in a high-pressure continuous homogenizer, operated at about $200 \mathrm{~kg} \mathrm{~cm}^{-2}$ pressure and temperature of $55^{\circ} \mathrm{C}$. Homogenization retards fat separation (creaming) and improves the water-binding properties of milk proteins (casein).

Heat treatment: The homogenized milk was heated to about $90^{\circ} \mathrm{C}$ for $5 \mathrm{~min}$ for increasing the water-binding capacity of milk proteins and denaturation of the whey proteins. At the same time, the milk mixture is pasteurized, i.e., all pathogenic and most spoilage bacteria are inactivated.

Fermentation: The heated milk mixture is cooled to about $45^{\circ} \mathrm{C}$ and it is inoculated with a yoghurt culture. The yoghurt inoculums (wet a mixed culture of Lactobacillus 
bulgaricus and Streptococcus thermophilus in proportion of $3 \%$ of the milk mixture was incubated at $45^{\circ} \mathrm{C}$, after which a firm coagulum was formed. Set yoghurt was prepared by packaging the inoculated milk mixture into consumer cups and incubating the aseptically sealed packages at $45^{\circ} \mathrm{C}$ for $3-4 \mathrm{~h}$.

Mixing of yoghurt: The bulk-set yoghurt is cooled to $15^{\circ} \mathrm{C}$, the yoghurt containing date paste was prepared by gentle mixing of bulk yoghurt with about 10, 15 and 20\% of date palm fruit paste. The fruit product containing yoghurt was stored at refrigeration temperature.

Packaging: Yoghurt or inoculated milk mixture was usually packaged in plastic cups and sealed with aluminum lids which operate under aseptic conditions.

Cooling/storage: The sealed yoghurt cups are cooled and stored at about $5^{\circ} \mathrm{C}$. Refrigerated storage life was around 2-3 weeks.

\section{Physical properties of fortified yoghurt}

Setting time: The setting time of sample was recorded from the time of inoculation to just coagulum was formed and it was recorded in hours.

Determination of synersis: A sample of $100 \mathrm{~g}$ centrifuged at $25^{\circ} \mathrm{C}$ and whey was drained for $15 \mathrm{~min}$. The weight of drained whey reported as the percentage of synersis.

Proximate composition: The yoghurt prepared from different levels of paste was analyzed for physio-chemical characteristics such as $\mathrm{pH}$, moisture, protein and fat, total soluble solids and acidity has been determined as the procedures discussed.

Sensory analysis: The sensory evaluation of yoghurt was carried out by a 10 trained panel member comprised of postgraduate students and academic staff members of the faculty who had some previous experience in sensory evaluation of fruit and vegetable products. The panel members were requested in measuring the terms identifying sensory characteristics and in use of the score. Judgments were made through rating products on a 9 point Hedonic scale with corresponding descriptive terms ranging from 9 like extremely to 1 dislike extremely.

Statistical analysis: The analysis of variance of the data obtained was done by using Completely Randomized Design (CRD) for different treatments as per the methods given by Panse and Sukhatme. The analysis of variance revealed at significance of $\mathrm{p}<0.05$ level, S.E. and C.D. at $5 \%$ level is mentioned wherever required.

\section{RESULTS AND DISCUSSION}

In this present investigation, attempts have been made judge the suitability of date palm paste variety with varying levels for yoghurt fortification. Yoghurt is made by combining different levels of paste after fermentation. The product obtained was evaluated for its sensory and physico-chemical properties. In this investigation, there are in all seven treatments including control and the combinations are summarized:

Physical characterization of date palm fruits: The date palm fruit were cylindrical shaped and dark red in colour. The physical characteristics of date palm fruits used in the present investigation are shown in Table 1.

The data shows in Table 1 revealed that the average $1 \mathrm{~kg}$ of Berhi fruit contained about 125 fruits and $115 \mathrm{Safri}$ variety of date palm, respectively. The Berhi date palm fruit contained about on an average $89.25 \%$ flesh and Safri variety contained about 83.91 flesh and 11.75 and $17.09 \%$ pit, respectively. Similar results were obtained as stated by Jahromi et al. (2007).

Proximate composition of date palm fruit: The data pertaining to proximate analysis of Berhi and Safri date palm fruits was recorded and shows in Table 2. The purpose of finding the chemical composition was to study the effect of date composition on physiochemical and sensory quality of yoghurt. The data in Table 3 showed that there was significant difference in two

Table 1: Yoghurt with different levels of dale paste

\begin{tabular}{ll} 
Samples & Variety/Concentration fruit pulp \\
\hline C & Control without date paste \\
B10 & Yoghurt with $10 \%$ date paste of Berhi variety \\
B15 & Yoghurt with $15 \%$ date paste of Berhi variety \\
B20 & Yoghurt with $20 \%$ date paste of Berhi variety \\
S10 & Yoghurt with $10 \%$ date paste of Safri variety \\
S15 & Yoghurt with $15 \%$ date paste of Safri variety \\
S20 & Yoghurt with $20 \%$ date paste of Safri variety \\
\hline
\end{tabular}

Table 2: Physical characters of date palm (Phoenix dactylifera L.) fruit

\begin{tabular}{lrr}
\hline Physical parameters & Berhi fruit & Safri fruit \\
\hline Number of fruit $\mathrm{kg}^{-1}$ & 125.00 & 115.00 \\
Weight of fruit $(\mathrm{g})$ & 8.00 & 8.70 \\
Weight of seed $(\mathrm{g})$ & 0.86 & 1.40 \\
Weight of flesh $(\mathrm{g})$ & 7.14 & 7.30 \\
Fruit flesh $(\%)$ & 89.25 & 83.91 \\
\hline
\end{tabular}

Table 3: Proximate analy sis of date palm (Phoenix dactylifera $L$.) fruit

\begin{tabular}{lrr}
\hline Parameters & Berhi & Safri \\
\hline Moisture (\%) & 14.70 & 15.30 \\
Fat (\%) & 0.40 & 1.80 \\
Protein (\%) & 2.03 & 2.60 \\
Carbohydrate (\%) & 78.02 & 77.53 \\
Ash (\%) & 2.80 & 2.60 \\
\hline
\end{tabular}




\section{Res. J. Dairy Sci., 4 (2): 12-17, 2010}

categories in respect of various parameters of proximate analysis. As regarded moisture percentage in fruit of two categories, it is clear from the data that Safri fruit found to contain significantly more moisture $(15.30 \%)$ than Berhi variety $(14.7 \%)$.

The Safri fruit contained more fat $(1.8 \%)$ and protein $(2.60 \%)$ as compared to other category. In respect of carbohydrate, the Berhi date fruit contains more carbohydrate to Safri date fruit as it contained carbohydrate $(78.2 \%)$. With regards to ash, it is evident that Safri fruit $(2.6 \%)$ recorded low ash then Berhi fruit $(2.8 \%)$. But the difference in the fat content is quite significant. A difference in chemical composition of varieties is obvious as the processing of these fruits differ (Tafti and Fooladi, 2006).

Physico-chemical characters of date palm paste: As shown in Table 4, the Berhi fruit paste contained higher total soluble solids $\left(58^{\circ} \mathrm{Bx}\right)$, carbohydrate $(87.62 \%)$ and acidity (0.77) while Safri variety reported to be superior in terms of protein, fat and moisture content.

The difference in chemical composition of paste of different varieties is obvious as the processing variations and difference in their fruit composition.

\section{Physical properties of date paste fortified yoghurt}

Settling time: Table 5 showed that the use of date palm paste different concentration affected significantly on setting time of fortified cow milk yoghurt. Setting time of yoghurt reduced with increased in the concentration of the fortification.

The minimum setting time was observed in sample $\mathrm{S} 20$ (4.5 h) among all samples while maximum settling time was reported in control sample $(8.0 \mathrm{~h})$. Reduction in setting time of fortified yoghurt of present investigation is due to the increase in concentration of date palm paste. Hence, it is clear from the above readings that settling time is inversely related to levels of date paste incorporation.

Londsted (1974) reported the coagulation time of 5-6 h whereas Rao et al. (1982) reported the coagulation time of yoghurt in the range of 5-7 h with different culture combination. Gregory reported that interaction of pectin as protective hydrocolloid associated with casein in low $\mathrm{pH}$ milk product with effect of two different commercial pectins on setting time of yoghurt. The present results are in close confirmation with these findings.

Synersis: The data in Table 5 showed that the yield of synersis influenced significantly by increase in acidity of
Table 4: Physico-chemical characters of date palm (Phoenix dactylifera L.) paste

\begin{tabular}{|c|c|c|c|c|c|}
\hline \multirow[b]{2}{*}{ Parameters } & \multicolumn{2}{|c|}{ Varieties } & \multirow[b]{2}{*}{ Mean } & \multirow[b]{2}{*}{ SD } & \multirow[b]{2}{*}{$\mathrm{SE} \pm$} \\
\hline & Berhi & Safri & & & \\
\hline Total soluble solids ( $\left.{ }^{\circ} \mathrm{bx}\right)$ & 58.00 & 56.20 & 57.100 & 1.272792 & 0.900 \\
\hline $\mathrm{pH}$ & 4.09 & 4.11 & 4.100 & 0.014142 & 0.010 \\
\hline Acidity (\%) & 0.77 & 0.67 & 0.720 & 0.070711 & 0.050 \\
\hline Moisture (\%) & 45.60 & 48.20 & 46.900 & 1.838478 & 1.300 \\
\hline Fat $(\%)$ & 0.50 & 1.40 & 0.950 & 0.636396 & 0.450 \\
\hline Protein (\%) & 2.13 & 2.71 & 2.420 & 0.410122 & 0.290 \\
\hline Carbohydrate (\%) & 87.64 & 86.23 & 86.935 & 0.997021 & 0.705 \\
\hline $\operatorname{Ash}(\%)$ & 3.10 & 3.00 & 3.050 & 0.070711 & 0.050 \\
\hline
\end{tabular}

Table 5: Effect of varying concentrations of date paste on settling time and synersis of yoghurt

\begin{tabular}{lcc}
\hline Treatments & Settling time $(\mathrm{h})$ & Synersis (\%) \\
\hline C & 8.0 & 20.00 \\
B10 & 7.5 & 27.80 \\
B15 & 6.0 & 24.60 \\
B20 & 5.0 & 21.07 \\
S10 & 7.0 & 22.43 \\
S15 & 5.5 & 23.23 \\
S20 & 4.5 & 21.20 \\
\hline
\end{tabular}

product. The yoghurt containing $10 \%$ paste of Berhi date sample B10 had significantly higher synersis. This may be due to higher acidity resulting in separation of whey and total solids. The minimum synersis was found in B20 and S20 21.07 and $21.20 \%$, respectively.

Chemical composition of date paste fortified yoghurt pH: The $\mathrm{pH}$ values of samples varied from 4.51-4.69. Table 6 shows the $\mathrm{pH}$ content of sample B20 (4.69) was maximum as compared to other samples. Minimum $\mathrm{pH}$ was recorded in sample $\mathrm{S} 10$ (4.51) with $10 \%$ paste of Safri date variety. The $\mathrm{pH}$ of yoghurt found to increase with increase in concentration of both varieties while $\mathrm{pH}$ reading were higher in Behri variety compared to Safri. This may be due to the more carbohydrate content of the Berhi variety being converted into acid in fermentation process. Tarakci and Erdogan (2003) reported $\mathrm{pH}$ values of yoghurt in the similar range as obtained during present study.

Acidity: It may observe from Table 6 that the acidity of fortified yoghurt was affected significantly due to addition of date palm paste. The acidity of fortified yoghurt found to increase with increase in concentration of date paste. O'Neil et al. (1979) who observed an increase in acidity with increase in concentration.

Moisture: The sample $\mathrm{S} 20$ has maximum moisture $(77.18 \%)$ treated samples followed by S1 5 (77.08). Sample B10 (69.37\%) was with minimum moisture content among the samples of fortified yoghurt samples. In case of Safri variety, the decrease in moisture content is more significant. These results are similar to the results obtained by Hashim (2007). 
Res. J. Dairy Sci., 4 (2): 12-17, 2010

Table 6: Effect of addition of varying concentration of date paste on chemical composition of yoghurt

\begin{tabular}{lllllll}
\hline $\begin{array}{l}\text { Treatments } \\
\text { (yoghurt) }\end{array}$ & pH & $\begin{array}{l}\text { Acidity } \\
\text { (lactic } \\
\text { acid) }\end{array}$ & $\begin{array}{c}\text { Moi sture } \\
(\%)\end{array}$ & $\begin{array}{c}\text { Fat } \\
(\%)\end{array}$ & $\begin{array}{c}\text { Protein } \\
(\%)\end{array}$ & $\begin{array}{c}\text { Total soluble } \\
\text { solids } \\
(\% \mathrm{bx})\end{array}$ \\
\hline C & 4.47 & 1.03 & 85.91 & 3.18 & 3.24 & 14.58 \\
B10 & 4.54 & 0.97 & 69.37 & 3.27 & 3.25 & 24.2 \\
B15 & 4.64 & 0.94 & 74.19 & 3.58 & 3.38 & 26 \\
B20 & 4.69 & 0.87 & 74.94 & 3.71 & 3.42 & 27.8 \\
S10 & 4.51 & 0.92 & 77.08 & 4.36 & 3.35 & 23 \\
S15 & 4.58 & 0.89 & 77.18 & 4.61 & 3.43 & 24.2 \\
S20 & 4.63 & 0.87 & 79.43 & 4.87 & 3.47 & 26.2 \\
Mean & 4.58 & 0.927143 & 76.87143 & 3.94 & 3.362857 & 23.71143 \\
SD & 0.078316 & 0.058513 & 5.092031 & 0.670721 & 0.089016 & 4.330387 \\
S.E 5 & 0.029601 & 0.022116 & 1.924607 & 0.253509 & 0.033645 & 1.636732 \\
\hline
\end{tabular}

Fat: There is significant difference in the fat content of the yoghurt containing two different variety of date paste. It has seen that Safri variety imparted more fat than the Berhi variety as the date paste of Safri variety was containing more fat than the Berhi variety. While, surprisingly S15 contained higher fat per cent i.e., 4.61 compared to S20 (4.87).

Protein: Safri variety found to impart more protein content Berhi variety as shown in Table 6 . Protein content ranges from 3.45-3.47\%. Tarakci and Erdogan (2003) reported protein content of yoghurt in the same range obtained in present study.

Total soluble solids: Total soluble solids of yoghurt varied from 14.58 (control) to 27.8 (B20). From Table 6, it was recorded that Safri variety found to contain lower total soluble solids compared to Behri variety. Among treated samples, lowest TSS was observed in yoghurt containing $10 \%$ paste of safri variety. The total soluble solid found to increase with increase in date paste concentration in yoghurt. But the total soluble solid is more in the case of Berhi variety than the Safri date variety.

Sensory evaluation of yoghurt fortified with date paste added after fermentation

Appearance: The sample S10 containing 10\% of Safri date palm paste found to have highest score to control sample (plane yoghurt) followed by B10 containing 10\% of Behri paste which is similar in appearance as that of control sample. It is learned that at lower concentration, date palm paste improves the appearance property, however further increase in concentration resulted in decrease in appearance of product. This may be due to reduction in water holding capacity of the curd mass as it affects the protein interaction during coagulation process, resulting into more yield of synersis.

Colour: The difference in colour of the fortified yoghurt at lower concentration were highly significant due to addition of different concentration date palm paste of
Table 7: Sensory analysis of yoghurt with different concentration of date paste

\begin{tabular}{lcccccc}
\hline & & & & & & $\begin{array}{c}\text { overall } \\
\text { Treatments }\end{array}$ \\
Appearance & Colour & Flavour & Taste & Texture & acceptability \\
\hline Control & 7.5 & 7.0 & 7.2 & 7.5 & 7.4 & 7.3 \\
B10 & 7.8 & 7.5 & 7.4 & 7.8 & 8.2 & 7.8 \\
B15 & 6.8 & 7.1 & 7.6 & 7.2 & 7.3 & 7.1 \\
B20 & 6.5 & 6.6 & 7.2 & 6.8 & 7.2 & 6.8 \\
S10 & 7.7 & 7.4 & 8.3 & 8.6 & 8.0 & 8.0 \\
S15 & 7.2 & 7.1 & 8.4 & 7.8 & 7.5 & 7.5 \\
S20 & 6.8 & 7.0 & 7.2 & 7.1 & 7.4 & 7.0 \\
\hline
\end{tabular}

different variety. Among the all sample, the yoghurt having $\mathrm{B} 10$ with $10 \%$ concentration of paste of Behri date fruit was scored maximum score for colour i.e., 7.5. Control sample (Plain yoghurt) was not superior to other fortified yoghurts. It means that as compared to plain yoghurt, colour was improved due to addition of date paste. However, further increase in concentration beyond 10\% resulted in decrease in color acceptability even if the intensity of color was increase. It could be concluded from color observation that consumer prefers light colored yogurt whereas darkly colored yogurt reduces acceptability. Behri varieties have better color properties than Safri.

Flavour: Flavour of fortified yoghurt was significantly influenced by date paste incorporation. For flavour, the sample $15 \%$ paste of Safri found to be superior amongst all the other samples. Further increase in concentration reduced flavour acceptability. This may be due to further increase in concentration resulted in increasing the alcoholic aroma and acidic taste of yoghurt. So, the minimum concentration should be preferred for the maximum flavour score.

Taste: The taste of fortified yoghurt was influenced significantly due to addition of date paste. From the Table 7, it was observed that sample S10 (8.6) with $10 \%$ paste of Safri variety were scored maximum in taste. The $10 \%$ concentration was more preferred than 15 and $20 \%$ paste of both date variety paste in yoghurt. The taste of sample S10 was liked extremely to the judging panels. As it is natural sweetener, it enhanced the taste of yoghurt. Fortified S10 yoghurt was superior to control sample (Plain yoghurt). It means that as compared to plain yoghurt, taste was improved due to addition of date paste prior fermentation of milk.

Texture: It is noted from Table 7 that the texture of fortified yoghurt was affected significantly due to addition of different concentration and variety date palm paste. It is revealed that higher level of concentration of fruit paste and reduced the score for texture. Texture was generally affected due to separation of whey at high level of paste due to production of acids, to give the reduced coagulation and formation of soft and loose textured curd. 


\section{Res. J. Dairy Sci., 4 (2): 12-17, 2010}

The score of fortified yoghurt was good as compared to control sample. With respect to the highest score of $(8.2 \%)$ was obtained to sample B10 followed by sample S10 8.0 and S1 5 with score 7.5 .

Overall acceptability: As shown in Table 7, B10 and S10 sample were superior to control sample (Plain yoghurt). It means that overall acceptability was improved due to addition of date paste. Among the all the treatments, S10 having the maximum score i.e., 8.0.

\section{CONCLUSION}

Present investigation was undertaken to study the effect of date paste of two variety viz. Berhi and Safri and physiochemical properties and organoleptic properties of yoghurt. About 7 samples were prepared by different concentration of date paste with one control. Date palm variety i.e., Berhi was found to contains higher TSS, mineral and fibre than Safri variety. It also has been found that the per cent paste obtained from $1 \mathrm{~kg}$ of Berhi variety date was more than Safri variety. It was found that increase in concentration of date paste in yoghurt decreases setting time irrespective of variety. With respect to synersis of yoghurt, synersis decrease with increasing concentration of paste. The acidity, moisture and total soluble solids was found to increase with increasing concentration of date paste in case of sample.

Organoleptic evaluation with colour, appearance, flavour, taste and overall acceptability showed highly significant effect due to addition of date paste. Yoghurt containing $10 \%$ of date paste found to be superior compared to control in case of both variety and treatment.

It is concluded from the present investigation that the use of date paste improved the qualities of the fortified cow milk yoghurt at lower concentration up to $10 \%$. While with respect to varieties, Safri was more suitable than Behri variety for yoghurt fortification. Hence, it is concluded that addition of $10 \%$ Safri date paste in yoghurt improves the organoleptic as well and physico-chemical properties of yoghurt.

\section{REFERENCES}

AOAC, 1990. Official Methods of Analysis. 15th Edn., Association of Official Analytical Chemists, Washington DC. USA., pp: 200-210.

Ahmed, J. and H.S. Ramaswamy, 2006. Physico-chemical properties of commercial date pastes (Phoenix dactylifera). J. Food Eng., 76: 348-352.

Al-Shahib, W. and R.J. Marshall, 2003. The fruit of the date palm: Its possible use as the best food for the future. Int. J. Food. Sci. Nutr., 54: 247-259.
Hashim, I.B., 2007. Effect of cooling temperature and defrosting time on date quality during cold storage. The 7th Annual U.A.E. University Research Conference, pp: 1-10.

Helferich, W. and D.C. Westhoff, 1980. All About Yogurt. Prentice Hall Inc., Eglewood Cliffs, New Jersey.

Jahromi, M.K., A. Jafari, S. Rafiee, A.R. Keyhani, R. Mirasheh and S.S. Mohtasebi, 2007. Some physical properties of date fruit (cv. Lasht). Agricultural Engineering International: the CIGR Ejournal. Manuscript FP 07 019. Vol. 9. August. http://www. cigrjournal.org/index.php/Ejounral/article/view/887 $/ 881$.

Londsted, E.R.I.K., 1974. Improved methods for manufacture yoghurt. Am. Dairy Rev., 36: 36-38.

Meydani, S.N., 2006. Is Frozen Yoghurt as Nutritive as Regular Yoghurt: A Review. USDA Human Nutrition Research Center, England, UK.

Miller, G.D., D.D. DiRienzo, M.E. Reusser and D.A. McCarron, 2000. Benefits of dairy product consumption on blood pressure in humans: A summary of the biomedical literature. J. Am. Coll. Nutr., 19: 147S-164S.

O'Neil J.M., D.H. Klen and L.B. Har, 1979. Consistency and compositional characteristics of commercial yogurt. J. Dairy Sci., 62: 1032-1036.

Rao, K.R.S., N. Krishnappa and V.K. Nambudripad, 1982. Standardization of the method of preparation of yoghurt at room temperature. Indian J. Nutr. Diet., 19: 149-152.

Rasic, J. and J.A. Kurmann, 1978. Yoghurt: Scientific Grounds, Technology, Manufacture and Preparations. Vol. 1, Technical Dairy Publishing House, Copenhagen, Denmark.

Robinson, R.K. and A.Y. Tamime, 1975. Yoghurt: A review of the product and its manufacture. Int. J. Dairy Technol., 28: 149-163.

Sarkar, S. and A.K. Mishra, 1998. Probiotic yogurt for infant feeding. Indian Food Industry, Vol. 17.

Tafti, A.G. and M.A. Fooladi, 2006. Study on the physicochemical properties of Iranian Shamsaei date at different stages of maturity. World J. Dairy Food Sci., 1: 28-32.

Tarakci, Z. and K. Erdogan, 2003. Physical, chemical, microbiological and sensory characteristics of some fruit-flavored yogurt. Vet. Fak. Derg., 14: 10-14.

Vinderola, C.G., N. Bailo and J.A. Reinheimer, 2000. Survival of probiotic microflora in Argentinian yogurths during refrigerated storage. Food Res. Int., 33: $97-102$.

Yousif, A.K., A.F. Alshaawan, M.Z. Mininah and S.M. Eltaisan, 1987. Processing of date preserve, date jelly and date jutter. Date Palm J., 5: 73-86. 